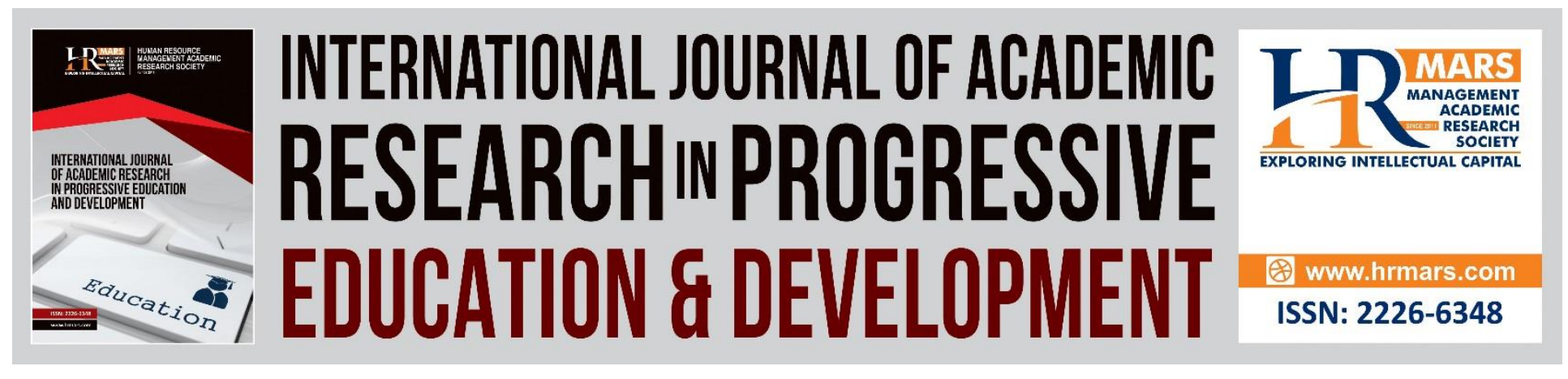

\title{
Teacher Ethical Principles and Practice in Seventh-day Adventist Secondary Schools in Same District of Kilimanjaro Region of Tanzania
}

Abrahim Youze, Hotamo Fanta, Yona Balyage, Lazarus Ndiku Makewa

To Link this Article: http://dx.doi.org/10.6007/IJARPED/v3-i1/681

DOI: 10.6007/IJARPED/v3-i1/681

Received: 15 January 2014, Revised: 19 February 2014, Accepted: 28 February 2014

Published Online: 22 March 2014

In-Text Citation: (Youze et al., 2014)

To Cite this Article: Youze, A., Fanta, H., Balyage, Y., \& Makewa, L. N. (2014). Teacher Ethical Principles and Practice in Seventh-day Adventist Secondary Schools in Same District of Kilimanjaro Region of Tanzania. International Journal of Academic Research in Progressive Education and Development, 3(1), 106-124.

Copyright: () 2014 The Author(s)

Published by Human Resource Management Academic Research Society (www.hrmars.com)

This article is published under the Creative Commons Attribution (CC BY 4.0) license. Anyone may reproduce, distribute, translate and create derivative works of this article (for both commercial and non-commercial purposes), subject to full attribution to the original publication and authors. The full terms of this license may be seen

at: http://creativecommons.org/licences/by/4.0/legalcode

Vol. 3(1) 2014, Pg. 106 - 124

http://hrmars.com/index.php/pages/detail/IJARPED

JOURNAL HOMEPAGE

Full Terms \& Conditions of access and use can be found at http://hrmars.com/index.php/pages/detail/publication-ethics 


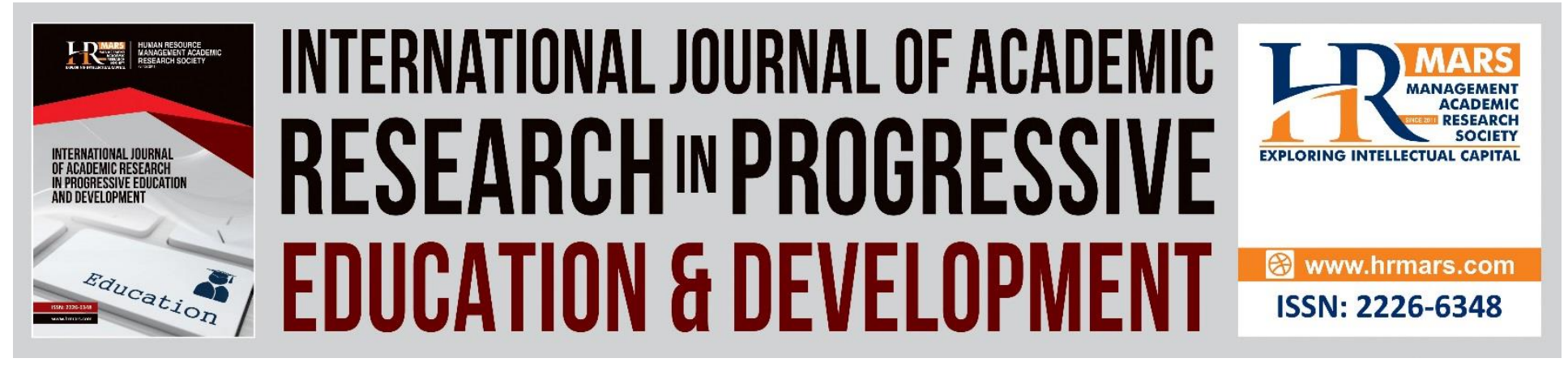

\title{
Teacher Ethical Principles and Practice in Seventh- day Adventist Secondary Schools in Same District of Kilimanjaro Region of Tanzania
}

\author{
Abrahim Youze, Hotamo Fanta, Yona Balyage \\ University of Eastern Africa, Baraton \\ Email: abrahamryouze@yahoo.com, fhotamo@yahoo.com, balyagey@gmail.com
}

\author{
Lazarus Ndiku Makewa (Corresponding Author) \\ University of Eastern Africa, Baraton \\ Email:ndikul@gmail.com
}

\begin{abstract}
The intention of this study was to find out how students from Adventist secondary schools in Same District of Tanzania evaluated their teachers' practice of ethical principles. The evaluation addressed the following research variables: behavior and conduct of teachers, relationship of teacher with both students and fellow workers, assessment of teachers' performance of duties and finally teachers' personality. The study used descriptive - comparative research design based on a cross- sectional survey. Questionnaires were administered to two groups, namely, teachers and students, three hundred twenty two being students (322) and thirty five (35) teachers. The findings revealed that while teachers evaluated themselves and their fellow workers as best, students rated their teachers' practice of ethical principles as averagely good. On the contrary, students and teachers indicated that cases of teachers having sexual encounters with students, teachers requesting for financial, sexual and other favors from students or family members and unfair treatment of students do occur. Generally, the study revealed that teachers related well with fellow workers, participated in beneficial activities for the school and communicated with kind words. However, students noted that teachers were not treating them equally and fairly. Keywords: Teacher, Ethical Principles, Practice, Seventh-day-Adventist, Tanzania
\end{abstract}

\section{Introduction}

Companies and institutions operate on principles that help them achieve their objectives. Without codes of ethical principles, one can be quick to react to unethical behavior in the making of choices. This would prevent someone from making good choices in life. While operating without principles is not good for individual behavior, it is even worse when it is practiced in an 
organization or institution. It leads to people acting without understanding the values they are supposed to subscribe to (Dalio, 2011).

According to Starratt (2004), ethics are the principles, beliefs, assumptions and values that characterize a moral life. Ethical teaching and leadership require that the educator action should be based on the principles, beliefs, assumptions and values that are espoused in the individual's profession. Ethics norms are important because they give people a baseline of the concept of right and wrong. They also require people to prepare themselves to react to a situation long before it takes place.

A secondary school, like any other community, is made up of a diversity of populations with different relationships. Some may be between academic and non-academic staff; some may share in both, as in the relation between teacher and student. Therefore to avoid conflicts, such improper relationship, indiscipline, partiality in assessing students and teachers, there is need for a guideline that determines what is right and what is wrong. According to Deaton (2010), though complex, the ethical theories align with common sense ethical principles. People accept such principles as 'treat one another with respect' and 'treat others as you would like to be treated'. Ethical principles do appeal to anyone, regardless of creed, religion, race or culture they subscribes to.

Kritsonis (2007) points out that ethical conduct inspires a quality of behavior that exemplifies honor and dignity for oneself. In a school situation, teachers, administrators, staff and school board members need to understand the importance of ethical conduct in the educational arena. An effective educational organization entails the need of individual people in maintaining integrity and good morals. According to Holloway (2006), character education promotes ethical values, creates a caring school community, and engages the group leader to instill moral values in their subjects. Kritsonis (2007) adds that ethical norms supply rules which serve as guidelines to be used as a basis for making decisions in a particular situation. Ethics in leadership deals with what leaders ought to do. The way leaders respond to a given situation and the choices they make are led by ethical norms. The concerns of school leaders in ethics are issues of justice, fairness and truthfulness. One must be sensitive to the needs of others, care for them and treat them in a way that is just and fair.

The Tanzanian code of ethics that govern teachers' behavior ensures that the school environment supports and nurtures students and employees in school. The fact that a child has a right to education, this means that teachers need to place students' welfare as a first priority. According to the Association of American Education (1994), teachers are ethically bound to perform better at job than other employees. They should strive to learn new techniques of behavior in everyday life, ideas and ideals to guide their conduct as they serve as role models to learners.

According to Weinstein (1999), Tanzanian children look to the culture at large for ethical guidance, and many adults are not setting good example. The importance of a parents' influence on a child is recognized by the impact it has on society. Much responsibility lies in the hands of the parents to help the child become a more responsible adult in society. Unfortunately, parents in modern society do not have enough time with their children; the role of a parent is played either by a house boy or a maid, whose ethical understanding in rearing children is very much 
limited. The only remaining alternative is the teacher who spends most of the time in school with students. Unfortunately, some teachers do not adhere to the professional codes of conduct. According to Chumi (2001), teachers sexually abuse their students in words and action.

Barrett (2005) points out that, the Tanzanian press and other media regularly reported on the teacher misbehavior towards students. Further, there are some cases of professional misconduct amongst school, college and university teachers. He pointed out cases where some teachers were implicated in sexual related behaviors with their clients. Some were involved in theft, and academic dishonesty. According to Chumi (2001), ethical principles are deteriorating and weakening, with teachers engaging in immoral acts ranging from verbal harassment to rape while others have sexually abused female and male students.

According to Habenitch (1998), general harassment such as sexist comments and innuendos, probably is quite frequent, even on Adventist campuses. Female students are said to be asked to provide sexual favors in exchange of grades, mentoring, and career advancement. On sexual abuse within schools, the General Conference of S.D.A Church (Melgosa, 2004) urged schools to devise and publicize their own policies which guided the moral conduct of teachers. Most literature address indiscipline cases of students but there is less material on how teachers violate their codes of ethics when dealing with clients. This study sought to evaluate Teachers' practice of ethical principles in Seventh-day Adventist Secondary Schools in Same District of Kilimanjaro Region of Tanzania.

\section{Theoretical Framework}

The foundation of this study will be on Immanuel Kant's theory of deontological ethics, which confirms that the ethical decisions are not simply one of morals, but of duty and justice (Penslar, 1995). This theory suggests that some acts are termed wrong and some right depending on the outcome of rules. According to Geisler (1971), deontological ethics is concerned with ethical norms or standards as expressed in the rules and standards set by the members of the profession or organization responsible for employing workers. The deontological theory affirms that people should hold fast to their obligations and duties when analyzing ethical dilemma. This means that a teacher will follow his or her obligation to students, fellow teachers or society because upholding one's duty is what is considered ethically correct (Ridley, 1998). Teachers who pursue this theory bring into being very steady decisions since they will be based on ethical codes that govern their set of duties (Penslar, 1995). In other words, rules are set to be a standard of what ought to be done and there is no room for conditions prevailing at the time of executing one's duties. Therefore, teachers will have to dress neatly, use good language, treat students fairly and respect both students and fellow teachers.

\section{Literature Review}

Ethical Principles

Starratt (2004) defines ethics as the principles, beliefs, assumptions and values that characterize a moral life. Ethical teaching and leadership require that the educator act based on the principles, beliefs, assumptions and values that are espoused in the individual's system of ethics. 
According to the American Sociological Association (1997), a professional Code of Ethics is a public statement prescribing ethical principle of specific profession. It prescribes the way the principles should be applied in order to promote the highest standards of professional service. Ethical principles are intended to guide, educate, motivate and inspire members of the profession in the process of carrying out their duties. At the same time, the Teachers' Code of Ethics is also a statement to learners, parents, and the wider public about what may be expected of teachers as they carry out their professional roles. There is a widespread public expectation in the changing and diverse society that teachers in schools and early childhood centers treat people fairly, respect their autonomy, exercise responsible care towards those they teach, and attend to truth not only in what they say, but also in the veracity of what they teach. These are the broad principles upon which the code is based.

Taylor and Nolen (2005), observe that two general guiding principles seem to capture the essence of the ethical concerns. The first is to Do No Harm. This is a basic broad ethical principle that people in general use to govern their lives by virtue of their being human. It is a variant of ethical principles handed down through the centuries, like the Golden Rule 'do to others the way you would want them to do to you' Payne (2003). This is a core ethical principle in other professions such as medicine. Munson (2000) states that the judgment involved comes in defining what harm is, or choosing between different harms in the relationship between teacher and student. This principle stems from the basic premise that ethical guidelines must protect the rights of individuals affected by an evaluation.

On the other hand, Clecka (2010) explains that ethical principles guide the behavior of teachers as reflected in standards of the conduct described in the documents of professional associations for teachers and codes of ethics published by disciplinary associations, such as the American Chemical Society, the American Psychological Association, the American Sociological Association, and the Modern Language Association. In addition, college and university faculty handbooks often include a section that addresses ethical standards or expectations regarding the behavior of workers. Ethical standards for students may be found in official student handbooks or college and university catalogues, although standards for graduate students are also addressed in some of the professional and disciplinary association codes of ethics. These various documents embody shared beliefs that are intended to guide both the activities and the behavior of people engaged in the academic enterprise.

The American Psychological Association (1992) points out that faculty are guided by ethical principles that address their professional responsibilities as teachers, scholars, and, more generally, members of college and university communities. While some aspects of documents concerning ethical standards describe the behavior to be embraced, other aspects make clear what actions must be avoided.

Eagan (1990) says, students are guided by general ethical principles as teachers regarding their academic work. Academic honesty and intellectual integrity are central in the educational process. These two principles apply to academic work, including, but not limited to, papers, assignments, laboratory reports, exams, quizzes, exhibits, and performances. Violation of ethical standards would be grounds for action against a student. The situational context of the violation along with the institutional norms and regulations affect the path of action. Although some situations involving a student's alleged violation of ethical standards may warrant action on the 
part of a teacher or an administrative officer, other situations may warrant a hearing by a duly constituted committee to determine whether the alleged act occurred as well as the appropriate sanctions.

Nath and Cohen (2010) explain that some institutions of learning have an honor code that makes clear that cheating and other forms of academic dishonesty are violations of ethical standards. These codes typically obligate students to practice academic integrity and avoid engaging in academic misconduct, but also to take action when they believe others have engaged in academic misconduct. The action taken by a fellow student who witnesses the ethical digression can range from directly confronting the alleged perpetrator to reporting the alleged act to individuals acting on the part of the institution, who may find it appropriate to convene a hearing panel for a judicial process in which students usually play an important role.

\section{Teachers' Ethical Behavior}

Lashaway (1996) observed that educators facilitate students' access to knowledge; they have significant influence on the quality of life in local communities and beyond. Therefore, they have a responsibility to serve both their students and the public good. Teachers must be particularly cognizant of ethical obligations to their clients (students) who are subject to the authority of the school and have little power of their own.

In cases where the teacher has to treat his or clients fairly, Laster (1997) suggests that students often lack the maturity and capability of making moral judgments on their own, and may look to teachers for moral direction. Allison (2004) commented that, ethical tensions do exist within schools among individual teachers. A teacher may see a colleague mistreating a student and try to make a decision of whether or not to intervene in the situation. "The teacher cannot bring himself/herself to intervene; the teacher says that fear is the reason for their silence and that intervening is considered to be a breach of loyalty". This is a clear example of how teachers deal with ethics of their students and colleagues on daily basis.

The role of teacher in a school is not only limited to the teaching and Instructing students, but also involves training out high-quality student who can work effectively with the community and serve as a pillar of good moral conduct (Klecka, 2010).

There is a growing body of evidence globally indicating that teachers and lecturers engage in professional misconduct. So often, teachers are implicated in sexual related behaviors with their clients, theft, and academic dishonesty. In Tanzania, scholars have acknowledged widespread cases of professional misconduct amongst school, college and university teachers, and teacher educators, (Barrett, 2005).

Barret, et al (2006) developed a research study to investigate "teachers' perceptions of the frequency and seriousness of different categories of teacher misconduct. The researchers created a 34-item questionnaire to measure how serious the teachers perceived the various categories of misconduct. These questionnaires were distributed to 235 education professionals in South Carolina. The respondents rated the degree of misconduct that they perceived had occurred for each item listed on the questionnaire. The researchers used a factor analysis to measure the degree of seriousness that professional educators had attached to each of the misconduct categories. The results of the study yielded three areas of major misconduct: (a) student-teacher boundary violations, (b) carelessness in behavior, and (c) subjectivity in grading 
and instruction. The behaviors that were judged the most serious ethical violations were engaging in romantic relationships with students (94.1\%), allowing students to engage in romantic behaviors in the classroom (94,1\%), making derogatory remarks to students about a colleague (92.6\%), awarding students higher grades for favors (90.8\%), and making sexual comments to students.

The results of this research study suggest that teachers have an understanding of the underlying ethical principles of their profession. The researchers recommend that a set of principles should be compiled that mirrors those found in the code of ethics for the American Psychological Association (APA), and the American Medical Association (AMA). These principles include showing respect for others, delivering professional services, and helping others. The aforementioned set of principles could provide the guidance for a national code of ethics. Barrett et al. (2006) suggest that a national code of ethics would establish a standard for defining the expected ethical behavior of education professionals. The code of ethics would protect the public against incompetent educators and would also protect the educators who followed their professional code of ethics.

Pierce (1995) stated that most sexual harassment complaints are filed by girls, male teachers more often than female teachers reported that they were sexually attracted to students, had sexual fantasies about students, and engaged in sexual relationships with students.

Unfortunately some teachers have a negative way of understanding ethics. Discussing this, in his view, Covaleskie (2005) says the personal ethics for each individual teacher varies according to the teacher's belief of what is ethical. Each teacher may believe that their interpretation of ethics is being practiced in their behavior and in their personal lives and if this is true, then he/she is demonstrating ethical principles and virtues of a moral person and a moral professional. By demonstrating the characteristics of ethics and virtue in the classroom with the use of actions, attitudes and words make a positive impact on the many students that the teacher will come into contact with throughout their teaching career. Campbell (2005) summarizes this perspective by saying that this demonstration of ethics will also let the student know, "that if I respect you, then you can respect me."

\section{Teacher Ethical Relationship}

One of the most important talents that a teacher should long for is the ability to connect with students. It is referred to as an ability to cultivate relationships or be more formally labeled as nurturing pedagogy. It may be defined as a mix of high expectations and caring support; the student-teacher relationship, emotion-based experiences that emerge out of teachers' on-going interactions with their students. The importance of establishing a learner-centered environment features warm, supportive relationships with students (Silins \& Murray-Harvey, 1995). Mc-Ewan (2002) makes the case quite eloquently stating that effective teachers appear to be those who are human in the fullest sense of the word. Their classrooms seem to reflect miniature enterprise operations in the sense that they are more open, spontaneous, and adaptable to change. Good teaching is charged with positive emotion. It is not just a matter of knowing one's subject, being 
efficient, having correct competencies, or learning all the right techniques. Good teachers are not just well oiled machines. They are emotional, passionate beings who connect with their students and fill their work and classes with pleasure, creativity, challenge and joy (Hargreaves, 1994 \& Liu, 1997)

According to Roeser et al (1996), students who reported more positive teacher-student relationships also reported greater feelings of belonging, thus felt more academically efficaciousness and less self-conscious. In the same vein, Koplow (2002) proposed that effective student-teacher relationships encourage greater confidence and classroom engagement in much the same manner as sensitive parenting encourages a greater sense of security and confidence.

Saul (2005), who interviewed two distinct groups of Canadian students from the Atlantic coast as well as the Pacific coast, found that all students interviewed for the study noted the vital importance of the student-teacher relationship to their success. Looking at sexual relationship, Pierce (1995) commented that, sexual relationships with professional cohorts can lead to feelings of intimidation and hostility in the work environment. According to Soltis (1998), what makes a behavior ethical or unethical is whether that behavior is consistent with or contradictory to one's obligations. Given these conditions, there is always a gap between principles and behavior requiring judgment in a specific situation. Educators must be given space, autonomy, and support to learn to use their judgment. This approach, shows an important distinction between ethics and best practices in teaching and assessment. Ethics is addressed in terms of obligations based on relationships so there is an affective component as well as a rational one. More specifically, obligations are felt, but best practices are merely followed.

Bacchetti (1990) observes that for one to adopt the individual role of the teacher is an ethicsdriven undertaking. Since individuals in academia equate gaining knowledge with gaining power, one aim of teaching is to empower students to accept responsibility for the situations in their lives and the lives of others. A faculty member's effective handling of respect and civility issues of students can catapult her from instructor to a mentor or role model.

In his advice to teachers, the former president of Tanzania Mwalimu Julius Nyerere (1968), said upon graduating, teachers are expected, to relate and associate with pupils who are their immediate clients, and other interested parties in their respective societies. Professional ethics demand that teachers should consistently encourage positive behavior because education is an integral part of the teaching enterprise which they should encourage on daily basis. Hill (1997) emphasizes that practical use of the code of ethics is an occasional reminder to members, especially the new ones, that being a member of a profession entails an obligation to conform to standards of behavior is a contemporary society.

\section{Teacher Ethical Practice in Assessment}

Assessment is the process of observing and measuring learning. Assessments provide a teacher with a better understanding of what students are learning. Airasian, (2005 suggests that teachers weigh their obligations and make judgments related to classroom assessment. 
Studies suggest that poor assessment significantly affects students and when student evaluations are not sound, educational programs suffer. Poor student evaluations victimize and harm students. When questionable evaluation practices are employed in high-stakes situations, negative consequences are likely to draw attention (Campbell \& Greenberg, 1993; Taylor and Nolen, 2005).

According to Gullickson (1993), studies conducted since the early 1960s have consistently shown that teachers are not well prepared to conduct student evaluations. Nearly half of teacher education institutions provide no preparatory coursework in student evaluation or classroom assessment practices. In those that do, most instruction and supporting materials focus on testing, with little attention to how to organize, conduct, and use these assessments in the instructional settings they are intended to serve. As a result, teachers do not have adequate preparation to properly evaluate students, nor do they have strong support materials to guide their efforts.

Educators should assess fairly as they would wish to be assessed in a fair manner. Various authors consider ethical practices, but these discussions suffer from a lack of explicit identification of the underlying ethical assumptions related to making decisions about behavior in the realm of assessment (Steven, 2001; Payne 2003).

Teachers' knowledge base about guidelines or ethical codes may be uncertain because they often lack formal assessment training or their training has become dated (Stiggins, 1999). Conflicting norms related to teaching (e.g., institutional norms vs. ethical interpersonal norms) often place teachers in ethical dilemmas (Colnerud, 1997). But, teachers' ability to apply guidelines to a specific context has received limited attention in the literature. One exception is the Impara and Plake (1993) study in which five items in a test of teacher assessment competence measured teachers' ability to answer items related to ethical issues in student evaluation. These items, however, all focused on issues relating to standardized tests.

The content the teacher brings into the classroom questions the teacher's ethics of what "subject matter" they want to include in their instructions. The teacher has to decide whether there will be enough time to cover each skill of the content area. If there is, then some critical thinking skills to be included in the content even though the school may not require its coverage. The teacher should decide what to do. He or she should not be tempted to leave out the difficult parts of the course content, when students will need it the most (Kienzler, 2000; Kovaleskie, 2005).

Promoting ethical practices in assessment is considered to be a very important goal of the organizations involved in assessment. Codes are intended to increase the awareness of ethical practice among their memberships and to promote ethical uses of assessment in various contexts: teaching, counseling, evaluation, research, among others, (Edgard, 2007). 
INTERNATIONAL JOURNAL OF ACADEMIC RESEARCH IN PROGRESSIVE EDUCATION AND

DEVELOPMENT

Vol. 3, No. 1, 2013, E-ISSN: $2226-6348$ @ 2013 HRMARS

\section{Teachers' Ethics in Performance of Duties}

Performance of teachers has been accepted as a multidimensional construct since it measures a variety of different aspects of teaching such as; subject mastery, effective communication, lesson preparation and presentation (Onyeachu, 1996).

According to Anangisye (2008), poor academic performance of students in Tanzania has been linked to poor teachers' performance in terms of accomplishing the teaching task, negative attitude to work and poor teaching habits, which have been attributed to poor motivation. It has also been observed that conditions that would make effective teaching such as resources available to teachers, general conditions of infrastructure as well as instructional materials in secondary schools in Tanzania are poor. These prevailing conditions would definitely show a negative influence on the instructional quality in schools, which may translate to poor academic performance (Blankstein, 1996; Starr, 2002; Joshua et al., 2006).

Studies show that embodying ethical knowledge gives the teacher the ability to practice their teaching skills with morals and ethics and not just viewing their job as being teaching only. The use of ethical knowledge by a teacher can be expressed by the way a teacher projects the tone of his/her voice towards the student, by avoiding student embarrassment and by reminding students of how their behavior can affect other classmates (Mwalimu, 2001; Campbell, 2005; Smith, 2001)

\section{Method}

This study aimed at finding out how students in Seventh-day Adventist schools in Same District evaluated their teachers in the practice of ethical principles governing their profession as Teachers. The design for this study was descriptive.

\section{Population}

Same district has only three Adventist Secondary Schools. The target population of this study were all the 35 teachers and 322 Form Three students in the three schools. Only form three students were used because this was the group in session when the fieldwork was carried out. Chome Secondary School consisted of 94 Form Three students and nine teachers, Parane Secondary School had 115 students and eight teachers while Suji Secondary school comprised of 113 students and 18 teachers. This number was large enough for this particular study and could be assessed easily in the given time limit.

\section{Sampling Techniques}

All Form three students and teachers in the three Adventist Schools in Same District were used in the study. This was informed by several reasons: since the total population was small, the whole population could be studied at minimal cost. Secondly, sampling error was eliminated since there was no sampling procedure. Finally, if a sampling method had been applied instead, then, virtually the entire population would have had to be sampled to achieve a desirable level of precision. The census provided the researcher with a panoramic view of Adventist Teachers 
practice of ethical values in Same District of Kilimanjaro Region in the United Republic of Tanzania.

\section{Research Instruments}

Questionnaires were used to collect data. This was because the instrument afforded the researcher to obtain responses concerning perceptions of students against their teachers' practice of ethical principles in Adventist Schools. The questionnaire afforded the researcher to capture the perception of all form three students in Adventist secondary school in Same District within the time limit. Moreover, it made certain the discretion and end results leading to openness and objective responses. The questionnaire consisted of three sections namely: the background information of the student, open ended questions on the areas of evaluation and lastly recommendations in relations to teachers' ethics in the school setting.

Teachers' questionnaire was also used to capture teachers' self evaluation against students' views as per the questionnaire set up. This was to bring about the element of comparing and contrasting responses from either side. This instrument was to be of much help to the researcher in judging the information required for this very study.

Reliability

According to Joppe (2000), Reliability was defined as the extent to which a questionnaire, test, observation or any measurement procedure produces the same results on repeated trials. It is the stability or consistency of scores over time or across raters.

To test reliability, a pilot study was conducted in Tukuyu and Iringa Districts. The questionnaire was distributed to students at Iringa Adventist Secondary School and Ndembela Secondary School. This was because students in Adventist Secondary Schools had similar characteristics with those in Same District. The questionnaire yielded an alpha of 0.7 or above which meant that the research instruments were reliable.

\section{Data Gathering Procedure}

The researchers acquired research permit from the University Research Committee, then an introduction letter from the Director of Graduate Studies at the University of Eastern Africa, Baraton, was availed. These documents were presented to the Ministry of Education and Vocational Studies of the United Republic of Tanzania. Thereafter, the schools were visited as planned for data collection.

\section{Results and Discussion}

This study examined the teachers' practice of ethical principles in Adventist Secondary Schools as evaluated by students in the following areas: a) Behavior b) Relationship c) Student Assessment d) Performance of duties and e) Personality.

The following scale was used to interpret the mean scores.

Mean score Interpretation or Evaluation

3.5-4.0 Strongly agree/ Excellent

2.5-3.49 Agree/good 
INTERNATIONAL JOURNAL OF ACADEMIC RESEARCH IN PROGRESSIVE EDUCATION AND

DEVELOPMENT

Vol. 3, No. 1, 2013, E-ISSN: $2226-6348$ @ 2013 HRMARS
$1.5-2.49$
Disagree/poor
1.0-1.49 Strongly disagree/poorest

\section{Behavior}

On the behavior of their teachers, students were asked six questions, whose responses are presented in Table 1

\section{Table 1}

\begin{tabular}{llllll}
\multicolumn{9}{l}{ Students' rating of their teachers on behavior } \\
\hline Statement & N & Min. & Max. & Mean & SD \\
\hline My teachers greet students in class & 322 & 1.00 & 4.00 & 3.41 & 1.00 \\
My teachers pray with students & 322 & 1.00 & 4.00 & 3.72 & 0.71 \\
before lesson & & & & & \\
My teachers are a good example & 321 & 1.00 & 4.00 & 2.68 & 1.12 \\
My teachers lead students to Jesus & 321 & 1.00 & 4.00 & 3.25 & 1.00 \\
My teachers respect students right & 322 & 1.00 & 4.00 & 2.77 & 1.20 \\
My teachers are honest and loyal to & 322 & 1.00 & 4.00 & 2.65 & 1.17 \\
authorities & & & & & \\
\hline Valid N (list wise) & & & & & \\
\hline
\end{tabular}

Key: min - minimum, max - maximum, SD - standard deviation; $\chi^{2}$ goodness of fit for all variables was significant at $P<.05$

Chi-square goodness of fit test was significant at $p<.05$ for all the questions asked of students, implying that the observed results were likely to be replicated in the population. With regard to behavior, teachers are likely to pray with their students before lessons, greet the students in class and lead the pupils to Jesus, since these questions had the highest means and the smallest standard deviations. However, the teachers scored lower marks on being honest and loyal to school authorities and being good examples with the means of 2.65 and 2.68, respectively, which implied that some of them tended to disagree.

The students' overall mean on teachers' behavior was 3.08. Laster (1997) suggests that students often lack the maturity and capability of making moral judgments on their own, and may look to teachers for moral direction. The importance of teachers being morally upright has been documented in many studies, for instance (Weinstein, 1999; Barrett, 2005; White 2000 \& Melgosa 2004). It is therefore important for teachers to be role models for their students. However, the finding in this study that many students do not find their teachers as good examples worth emulating and as being honest and loyal suggests that there is a deficiency in some behavioral aspects of teachers that should be bridged.

Relationship with students 
Vol. 3, No. 1, 2013, E-ISSN: $2226-6348$ @ 2013 HRMARS

The second ethical practice that the study investigated was the relationship between students and teachers. Table 2 presents the perceptions of students about student-teacher relationships, respectively.

Table 2

Students' rating of student-teacher relationships

\begin{tabular}{|c|c|c|c|c|c|}
\hline & $\mathrm{N}$ & Min & Max & Mean & Std. Dev. \\
\hline $\begin{array}{l}\text { My teachers relate well with pupils of opposite } \\
\text { sex }\end{array}$ & 320 & 1.00 & 4.00 & 2.9656 & 1.16992 \\
\hline $\begin{array}{l}\text { My teachers relate well with students of same } \\
\text { sex }\end{array}$ & 319 & 1.00 & 4.00 & 2.8464 & 1.15942 \\
\hline I have been harassed sexually by a teacher & 320 & 1.00 & 4.00 & 1.5469 & 1.06423 \\
\hline My teachers treat students fairly & 319 & 1.00 & 4.00 & 2.0157 & 1.19606 \\
\hline $\begin{array}{l}\text { Teachers request favours from students and } \\
\text { family }\end{array}$ & 321 & 1.00 & 4.00 & 2.0062 & 1.30861 \\
\hline
\end{tabular}

Key: min - minimum, max - maximum, std. dev. - standard deviation; $\chi^{2}$ goodness of

fit for all variables was significant at $\mathrm{P}<.05$

Tables 2 indicates that teachers related well with students of both the opposite sex and the same sex, because these variables had the highest means and lower standard deviations. That means that male teachers respected female students while female teachers did the same with male students. In addition, male teachers related well with male students, the female teachers had healthy relationship with female teachers. The existence of healthy relationships in the schools of study is a positive phenomenon that should be encouraged, because such harmonious relationships breed cooperation and togetherness that is necessary for the success of a school (Liu, 1997; Saul, 2005 \& Koplow, 2002).

Students' answers had mean score of 1.54 for the question asking students as to whether they had been sexually harassed by their teachers. This indicates that even in the Adventist institutions in which this study was conducted, there are some notable cases of teachers having sexual relations with students or sexually harassing their students. Students stated cases of teachers requesting for financial, sexual and other favors from students or families (mean, 2.00), This suggests that there were some cases of teachers asking for favors from their students. The findings of this study are in line with a series of other studies that have documented cases of sexual relationships between teachers and students (Barrett et al. 2006 \& Pierce 1995).

Relationship with Fellow Workers

The study also established how teachers in the sampled schools related with their fellow workers. According to students, results in Table 3 indicate that generally teachers related well with fellow workers (mean, 3.16), participated in beneficial activities for the school (mean, 3.02) and communicate with kind words (mean, 2.96). However, in line with the finding of the previous section, the results also showed that a few teachers had sexual encounters with fellow workers 
Vol. 3, No. 1, 2013, E-ISSN: 2226-6348 @ 2013 HRMARS

(mean, 2.29), a finding which is deplorable. School administrations should therefore be alive to these social undercurrents in their schools and take appropriate actions to address them. These findings are likely to apply to the rest of the population since the $\chi^{2}$ goodness of fit for all the variables was significant at $\mathrm{P}<.05$.

\section{Table 3}

Students' opinion on teacher-fellow worker relationships

\begin{tabular}{lccccc}
\hline & $\mathrm{N}$ & Min & Max & Mean & $\begin{array}{l}\text { Std. } \\
\text { Dev. }\end{array}$ \\
\hline $\begin{array}{l}\text { My teachers relate well with fellow workers } \\
\text { Teachers had sexual encounter with fellow }\end{array}$ & 321 & 1.00 & 4.00 & 3.1651 & 1.14052 \\
$\begin{array}{l}\text { workers } \\
\text { My teachers communicate with kind words }\end{array}$ & 319 & 1.00 & 4.00 & 2.2960 & 1.33567 \\
$\begin{array}{l}\text { My teachers participate in activities that benefit } \\
\text { school }\end{array}$ & 320 & 1.00 & 4.00 & 2.9624 & 1.19951 \\
\hline
\end{tabular}

Key: min - minimum, max - maximum, Std. Dev. - standard deviation; $\chi^{2}$ goodness of fit for all variables was significant at $\mathrm{P}<.05$.

The results suggested that teachers participated in beneficial activities, related well with fellow workers, and used kind words while communicating with workers. However, the results show that teachers may have had sexual encounters with their fellow workers as indicated by a mean of 2.30 . 
INTERNATIONAL JOURNAL OF ACADEMIC RESEARCH IN PROGRESSIVE EDUCATION AND

DEVELOPMENT

Vol. 3, No. 1, 2013, E-ISSN: $2226-6348$ @ 2013 HRMARS

\section{Table 4}

Teacher performance of duties according to students

\begin{tabular}{|c|c|c|c|c|c|}
\hline & $\mathrm{N}$ & Min & Max & Mean & $\begin{array}{l}\text { Std. } \\
\text { Dev. }\end{array}$ \\
\hline My teachers instruct to respect authorities & 322 & 1.00 & 4.00 & 3.5901 & .80087 \\
\hline My teachers mark assignments, tests and exams & 321 & 1.00 & 4.00 & 3.5452 & .83963 \\
\hline $\begin{array}{l}\text { My teachers give feedback of test, exams with } \\
\text { corrections }\end{array}$ & 322 & 1.00 & 4.00 & 3.4720 & .85425 \\
\hline $\begin{array}{l}\text { My teachers instruct to love and be loyal to } \\
\text { country }\end{array}$ & 320 & 1.00 & 4.00 & 3.4406 & 90777 \\
\hline $\begin{array}{l}\text { My teachers emphasize obedience to government } \\
\text { law as citizens duty }\end{array}$ & 319 & 1.00 & 4.00 & 3.4075 & .92658 \\
\hline $\begin{array}{l}\text { My teachers are prompt in producing students } \\
\text { reports }\end{array}$ & 320 & 1.00 & 4.00 & 3.2844 & 1.12135 \\
\hline My teachers do not miss a class & 319 & 1.00 & 4.00 & 3.2508 & 1.07566 \\
\hline My teachers work out well when on duty & 317 & 1.00 & 4.00 & 3.2271 & 1.04586 \\
\hline My teachers give assignments after the lesson & 320 & 1.00 & 4.00 & 3.1281 & 1.05305 \\
\hline $\begin{array}{l}\text { My teachers help closely those who seem not to } \\
\text { understand }\end{array}$ & 322 & 1.00 & 4.00 & 3.0807 & 1.02295 \\
\hline My teachers come to class on time & 319 & 1.00 & 4.00 & 3.0376 & 1.10680 \\
\hline My teachers are competent in the areas of study & 320 & 1.00 & 4.00 & 3.0000 & 1.05640 \\
\hline $\begin{array}{l}\text { Teachers assign students some work supposed to } \\
\text { be done by teachers }\end{array}$ & 322 & 1.00 & 4.00 & 2.9969 & 1.22665 \\
\hline $\begin{array}{l}\text { My teachers attend classes, listen and advice } \\
\text { students }\end{array}$ & 322 & 1.00 & 4.00 & 2.8727 & 1.13261 \\
\hline My teachers grade students fairly & 319 & 1.00 & 4.00 & 2.6708 & 1.25948 \\
\hline
\end{tabular}

Key: min - minimum, max - maximum, Std. Dev. - standard deviation; $\chi^{2}$ goodness of fit for all variables was significant at $P<.05$

The results suggest that teachers are likely to instruct their students to respect authorities, mark assignments, tests and examinations, give feedback and corrections on the examinations, emphasize obedience to government and the country, produce reports and faithfully attend classes, which all had high mean scores. Thus, in these aspects of ethics, teachers appeared to do well. However, the study found that some teachers failed to do well in other facets of ethical practice in teaching. For instance, some students felt that teachers do not grade them fairly, do not listen and advice them adequately, give them work which is supposed to be done by the teachers themselves, are not competent and some do not come to class on time, all which had lower means. The failure by teachers to accomplish ethical obligation to teaching have been supported by other studies such as those of Secretariat (2004) and Fullan (2003). 
INTERNATIONAL JOURNAL OF ACADEMIC RESEARCH IN PROGRESSIVE EDUCATION AND

DEVELOPMENT

Vol. 3, No. 1, 2013, E-ISSN: $2226-6348$ @ 2013 HRMARS

Teachers' Personality

The last ethical component of teachers investigated by this study was their personality. Table 5 presents the perceptions of students and teachers on the personality.

Table 5

Teachers' personality according to students

\begin{tabular}{|c|c|c|c|c|c|}
\hline & $\mathrm{N}$ & Min & Max & Mean & Std.Dv \\
\hline $\begin{array}{l}\text { Male teachers put on clean and } \\
\text { acceptable } \\
\text { clothes }\end{array}$ & 322 & 1.00 & 4.00 & 3.6056 & $\begin{array}{l}.7752 \\
2\end{array}$ \\
\hline My teachers dress neatly & 321 & 1.00 & 4.00 & 3.3894 & $\begin{array}{l}.9655 \\
4\end{array}$ \\
\hline My female teachers dress decently & 322 & 1.00 & 4.00 & 3.3634 & $\begin{array}{l}.9960 \\
8\end{array}$ \\
\hline $\begin{array}{l}\text { My teachers appearance portray positive } \\
\text { image of professionalism }\end{array}$ & 320 & 1.00 & 4.00 & 3.2719 & $\begin{array}{l}.9687 \\
1\end{array}$ \\
\hline
\end{tabular}

Key: $\min$ - minimum, max - maximum, Std. Dev. - standard deviation; $\chi^{2}$ goodness of fit for all variables was significant at $\mathrm{P}<.05$

The results indicated that generally, teachers are likely to have favorable personalities, as the mean scores of all the variables were greater than 3. Interestingly, more students felt that male teachers were likely to dress more acceptably and decently (mean, 3.6) compared to female teachers (mean, 3.36). The item which was given the lowest score by students was that "teachers' appearance portray positive image of professionalism", implying that some students felt that the appearance of their teachers was undesirable.

\section{Conclusions and Recommendations}

This study examined the perceptions of students on the ethical practices teachers in Seventh-day Adventist Secondary Schools located in a rural area around Mt. Kilimanjaro in Tanzania. The study established that while most teachers in the Adventist Secondary schools lived up to good ethical practices with regard to some of elements of their behavior, relationship with students, relationship with workers, performance of duties and their personalities, the study also found that teachers were deficient in other elements of ideal ethical practices. Some of the negative ethical practices that some teachers were involved in included not being good role models, engaging in sexual relations with their pupils and fellow workers, treating students unfairly, not grading students fairly, not listening and advising students adequately, not attending class on time, lacking competence and being dishonest to school authorities. School authorities and churches should organize seminars, conferences, workshops, and refresher courses for teachers in which the ethical conduct expected of teachers should be stressed. In addition, schools should avail to teachers handouts containing the ethos required of teachers and be availed to every teacher. 
INTERNATIONAL JOURNAL OF ACADEMIC RESEARCH IN PROGRESSIVE EDUCATION AND

DEVELOPMENT

Vol. 3, No. 1, 2013, E-ISSN: $2226-6348$ @ 2013 HRMARS

\section{References}

Airasian, P. (2005). Assessment in class room: A coscise approach (2nd ed.). Boston, MA: McGraw - Hill Company.

Allison, D. J. (2004). Reviews the book "Ethical Teacher", by Elizabeth. American Journal of Education, 111(1), 122-126.

American Chemical Society. (1994) The chemist's Code of Conduct and ASC Ethical Guidelines. www. Acs.org/membership/conduct.html.

American Sociological Association. (1997). American Sociological Association Code of Ethics Conduct. www.assnet.org

Anangisye, W. L. (2008). moral education and character development: learning from African indigenous education framework. Journal of Adult education, 16, 1-23.

Bacchetti, K., and Fauske, J. R. (2006). Educator sexual miscondut in schools: Impication for leadership preparation. Retrieved April 10 2012, from http://coe.ksu.edu/ucea/2006/Fauske UCEA 2006.pdf:

Barret, A. (2005). Teacher Accountability in context: Tanzania primary school teachers' perception of local community and education administration. Compare, 35(1), 43-61.

Barrett, D., Headley, K., Stovall, B., \& Witte, J. (2006). Teacher's perceptions of the frequency and seriousness of violations of ethical standards. The Journal of Psychology, 140(5), 421-434. Retrieved April 2, 2007, from ProQuest database.

Campbell, E. (2005). The Ethical Teacher. Philadelphia: Open University Press.

Campbell, P., \& Greenberg, S. (1993). Equity issues in educational research methods. In

S. K. Biklen \& D. S. Pollard (Eds.), Gender and education. Ninety-second yearbook of the National Society for the Study of Education, Part 1. Chicago: The University of Chicago Press

Colnerud, G. (1997). Teacher Ethics as a Research Problem syntheses achieved and new issues. Teachers and Teaching:Theory and Practice, 12(3), 365-385.

Covalenskie, J. (2005). Ethical Teachers: Ethical People. Philosophy of Education Year Book. pp. 34-136.

Dalio, R. (2011) Principles www.bwater.com/.../Principles/Bridgewa, date down loaded.

Eagan, K. (1990). Ethical codes. A Standard for Ethical Behavior National Association of Secondary School principals Bulletin, 74, 59-62.

Edgard, J., and Campos, S. P. (2007). The many faces of corruption: Tracking Vulnerabilities at the sector level. World Bank Publication.

Fullan, M. (2003) The Moral Imperative of School Leadership. Thousand Oaks, CA: Corwin Press

Furrer, C. (2003). Sense of Relatedness as a Factor in childrens academic Engagement and performance. Journal of Educational Psychology, 95(1), 148-162

Gullickson, A. (1993). Matching measurement instruction to classroom-based evaluation: Perceived discrepancies and needs.

Habenith B. (1998). Cases in Bioethics: Selections from the Hastings Center Report. 3rd

Ed. Boston: Bedford/St. Martin.

Hill, U., \& Tom, A. R. (1997). Teaching as a moral craft. London: Longman .

Holloway, J. (2006). Model Behavior. Principal leadership, 6(5), 44-46.

Impara, J. C., Plake, B. S. (1993). Educational Administrators' and teachers' knowledge of classroom assessment. Journal of School leadership, 3, 510-521. 
INTERNATIONAL JOURNAL OF ACADEMIC RESEARCH IN PROGRESSIVE EDUCATION AND

DEVELOPMENT

Vol. 3, No. 1, 2013, E-ISSN: $2226-6348$ @ 2013 HRMARS

Joppe, M. (2000). The Research Process. http://www.ryerson.ca/mjoppe/rp.htm_retrieved 30/08/2007.

Joshua, M. T., Joshua, A. M., Kritsonis, A. W. (2006). Use of Students' Achievement Scores as Basisfor Assessing Teachers' Instructional Effectiveness: Issues and Research Results.National Forum of Teacher Education Journal, 17(3): 1-13.

Kienzler, S., \& Pring, R. (2000). Education as a moral practive. Journal of moral education, 30(2), 101-112.

Klecka, V., and Milner, H. R. (2010). what dioes teacher education have to do with teaching?Implecations for diversity studies. . Journal for Teacher Education , 118-131.

Koplow, L. (2002). Creating schools that heal. New York: Teachers College Press

Koraleskie, B. (2005). Library as Place: Rethinking Roles, Rethinking Space. February 2005. Available www.clir.org/pub129abst.html

Kritsonis, W. (2007). Way of Knowing through the realms of meaning. Houston, TX: National Forum Press.

Lashaway, F., \& Frenstermacher, G. D. (1996). Some moral consideration on teaching as a profession, the moral dimensions of teaching. San Francisco: Jossey - Bass Inc.

Laster, Kand Xiawman. (1997). Teacher training for moral education in China. journal of moral education, 481-494.

Liu, J. (1997). The emotional bond between teachers and students: Multi-year relationships. Phi Delta Kappan, 79(2), 156-57

McEwan, E. (2002). 10 traits of highly effective teachers. Thousand Oaks: Corwin Press.

Melgosa, J. (2004) Journal of Adventist Education Professional Ethics for Administrators. 42: 5 vol 66, Issue 3.

Mugenda, M. O., and Mugenda, A. G. (2003). "Research methods: quantitative and qualitative approaches." ACTS Press Nairobi.

Munson, R. (2000). The Role of private tuition in secondary Education in Tanzania, a paper in education and moral development. 21, 96-110.

Nath, L., \& Cohen, R. (2005). Aspiration and reality in the teaching and learning of science in Tanzania. Unpublished doctoral dissertation. Edinburgh : University of Edinburgh.

Nyerere, J. (1968). The Power of Teachers: Freedom and sociolism. Dar -es- Salaam: Oxford University Press.

Payne, D. (2003). Applied educational assessment (2nd ed.). Belmont, CA.: Wadsworth Publishing.

Pierce, L., \& Fallona, C. (1995). Manner in Teaching: a study in observing and interpretting teachers' moral virtues. Teachers Education, 681-695.

Roeser, R. (1996). Perceptions of the school psychological environment and early adolescents' psychological and behavioral functioning in school: The mediating role of goals and belonging. Journal of Educational Psychology, 88, 408-422.

Secretariat, C. W. (2004). A framework of Citizenship Eduaction in Sierra - Leone. British Council.

Silins, H., \& Murray-Harvey, R. (1995, April). Quality schooling versus school performance: What do students and teachers think? Paper presented at the annual meeting of the American Educational Research Association, San Francisco, CA.

Saul, D. (2005). Education unplugged: Students sound off about what helps them learn. 
INTERNATIONAL JOURNAL OF ACADEMIC RESEARCH IN PROGRESSIVE EDUCATION AND

DEVELOPMENT

Vol. 3, No. 1, 2013, E-ISSN: $2226-6348$ @ 2013 HRMARS

Education Canada, 45(2), 18-20

Smith, J. (2001). Natural calssroom assessment Designing seamless instruction and assessment. Thousand Oaks, CA: Corwin Press.

Soltis, F., \& Chang, F. (1998). School Teacher moral Reasoning. Moral Development in the Professions: Psychology and applied Ethics. New Jersey: Lawrence Erlbaum Associates.

Starr, L. (2002). Measuring the Effects of Effective Teaching Education World. Retrieved October16 2005, from www.education-world.com/a_issues.shtml

Starratt, K., and Berger, E. (2004). Parents as partners in Education: The school and home working together. New York: Millan Publishing Company.

Steven, J. (2001). An Education in Ethics. California: Santa Clara University.

Stiggins, R. (1999). Evaluating classroom assessmemt training in teacher education programs. Educational management: Issue and practice, 18(1), 23-27.

Taylor, K., and Nolen, S. (2005). Classroom assessment: supporting teaching and learning in real classroom. Upper Saddle River, NJ.: Pearsom Educational, Inc. 